\title{
Washington's growth and opportunity act or Beijing's 'Overarching Brilliance': will African governments choose neither?
}

Article

Accepted Version

Davies, J. E. (2011) Washington's growth and opportunity act or Beijing's 'Overarching Brilliance': will African governments choose neither? Third World Quarterly, 32 (6). pp. 1147-1163. ISSN 1360-2241 doi:

https://doi.org/10.1080/01436597.2011.586228 Available at https://centaur.reading.ac.uk/40822/

It is advisable to refer to the publisher's version if you intend to cite from the work. See Guidance on citing.

Published version at: http://www.tandfonline.com/doi/abs/10.1080/01436597.2011.586228\#.VauYjigx9Ec

To link to this article DOI: http://dx.doi.org/10.1080/01436597.2011.586228

Publisher: Routledge

All outputs in CentAUR are protected by Intellectual Property Rights law, including copyright law. Copyright and IPR is retained by the creators or other copyright holders. Terms and conditions for use of this material are defined in the End User Agreement.

www.reading.ac.uk/centaur 
Central Archive at the University of Reading

Reading's research outputs online 
Washington's Growth and Opportunity Act or Beijing's 'Overarching Brilliance':

Will African Governments Choose Neither?

\author{
JOANNE E. DAVIES
}

(Consultant, African Studies Centre, University of Oxford)

\begin{abstract}
:
Growing criticism of Chinese engagement in Africa centres on the risk to African development posed by China's aggressive export policies and the threat to the Washington Consensus and African governance posed by China's 'non-interference' approach to engagement. This article challenges both these assumptions. The growth of Chinese trade has a wide range of impacts, depending on the sector in question, and the current terms of trade Washington extends to Africa under the auspices of the AGOA do not result in uniformly beneficial effects. With regard to African governance, it is argued that the 'Washington Consensus' has been based on competing and often muddled perceptions of US national interest. This fact tempers the regret felt at Washington's loss of influence over the good governance agenda. Evidence is provided to show that China can work within properly regulated countries and industries, if the African governments in question can provide fair, efficient and transparent environments in which to operate.
\end{abstract}

Although much has been written on the threat of China's power to both the Washington Consensus and the future of good governance in Africa, there needs to be a clearer understanding of what - if anything - will be lost if American influence is undermined on the continent. The preservation and cultivation of influence is significant to the competing interests in Beijing and Washington. In terms of concrete African development, however, the relevance of the competing agendas will be lessened unless and until the movement for good governance makes progress in Africa itself. After fifty years of post-independence aid, disillusionment with the western model of development assistance has set in among recipients and even some donors. The unhappy truth has been that, for all the carefully constructed tools and institutions of the Washington Consensus, it has failed repeatedly to achieve its objectives. From structural adjustment programmes, conditionality, and a focus on 
governance, none of the programmes or institutions of the western model has yet been ultimately successful in improving the lot of ordinary Africans in any durable way. ${ }^{1}$

There has been an explosion of commentary concerning the rise of China in the context of Africa's development agenda. Battle lines have been drawn between the 'Washington Consensus' and the 'Beijing Consensus', with Halper issuing a '...clarion call...that America is engaged in a global struggle to assert and sustain the primacy of western values'. ${ }^{2}$ Meanwhile, Brautigam offers some very persuasive arguments as to why the rise of China will not necessarily result in the wholesale undermining of western-sponsored African development. The rise of China presents a small window of opportunity. For the African continent truly to capitalize on this new element of competition in the development arena, it is crucial that two specific areas are strengthened. The first of these centres on the use and timing of trade preferences. The second factor focuses on good governance. These two factors are examined in tandem in this article as reform in one area will come to very little without complementary reform in the other. Taken together, these two factors will be crucial in determining how China's rise as a world power will impact, not only on the African continent, but also on the Washington Consensus model of development and on the role of the US in Africa. Africans should be free to determine which elements of which programme are the most useful for their countries and societies - with one crucial caveat. If the western model is rejected in favour of China's model of (politically) illiberal capitalism, will it be a case of African governing elites choosing what is in their interest at the cost of their own citizens? It is important to identify what is at stake if the Washington Consensus is overthrown in favour of Beijing's purported 'non-interference' approach. 
This article will examine the impact of both Beijing and Washington on the two areas of trade preferences with Africa, and supporting the governance agenda in Africa. There is a real urgency surrounding both of these issues because African governments at last hold some measure of influence. They have valuable assets to offer both the US superpower and the rising giant of China - each of whom need access to the resources of the continent, but both of whom also look to the African continent as one source of their diplomatic prestige. This may be more apparent in Beijing's determined courting of African governments and its insistence on their adherence to the 'One China' policy, but there is a powerful contingent within the American foreign policy making apparatus - and in American society itself - that has not abandoned America's sense of mission, and its firmly held belief in American exceptionalism. The investigation will turn initially to American trade preferences towards Africa, and their impact on Africa's ability to improve domestic manufacturing and export diversification. The focus is on the US African Growth and Opportunity Act (AGOA), which represents the type of favourable market access that African governments and development specialists have long been requesting. This is then followed by an analysis of the threats - or opportunities - that the rise of China might pose in this area. 


\section{Part I}

\section{The US, China and African Trade}

\section{Seizing the day: The AGOA and the impact of trade preferences}

As western economies contracted in the wake of the global economic crash, the developing world faced a sudden evaporation of export markets combined with a virtual cessation of capital inflows to Africa in particular. And yet Kapstein argues that, in 'one of the great ironies of history', Africa could emerge from the global recession as the only region that remains committed to global capitalism. ${ }^{3}$ This stems from a realization that one result of the crisis has been an increase in protectionism. Over recent decades the goal of trade liberalization has proved successful, in that tariffs on goods have declined from a worldwide average of over 25 per cent in 1980 to less than ten per cent today. ${ }^{4}$ Unfortunately, reports from both the World Trade Organization (WTO) and the World Bank warn that trade barriers are once again on the rise. Since October 2008, 66 restrictive trade measures have been proposed and 47 have been enacted, including India's ban on Chinese toys (although proposed 'Buy American' legislation has since been aborted). ${ }^{5}$ Protectionism reduces trade and imposes costs on those who instigate it, but for Africa, with its small domestic markets, the rise of protectionism through increased trade barriers to developed country markets is 'potentially deadly' ${ }^{6}$

There is a small ray of hope with regard to these trade barriers. In The Bottom Billion, Collier identifies export diversification as being a significant factor in promoting African growth. Competing globally in an export market, rather than in domestic monopolies, really does improve the productivity of African firms, but the problem 
remains how to get these firms over the initial starting 'hump' of competitiveness. Collier argues that initially what Africa needs is temporary protection from Asia. This policy, in which Asia rather than the West bears this burden of aiding African development, is politically (and morally) problematic, but the crucial word here is 'temporary'. Collier certainly does not argue that the Organisation for Economic Cooperation and Development (OECD) should therefore raise tariffs against Asia, rather that tariffs against competing products from Africa should be removed. This would go some way in addressing their lack of economies of scale, problems with infrastructure and lack of a skilled workforce. An important caveat is that this is a time-limited window of opportunity for Africa. By approximately 2015, OECD tariffs against Asia would no longer be high enough for there to be much scope for protecting Africa. ${ }^{7}$ However, although the opportunity might be narrow, it is hoped that the temporary nature of this solution would increase its potency in two ways: making it more acceptable to the Asian countries whose tariffs would temporarily remain in place; and focusing the minds of African policy makers who would have to structure policies and improve governance in order to facilitate the diversification of their exports in the time frame offered.

African manufacturers were given this very opportunity by Washington under the auspices of the African Growth and Opportunity Act (AGOA), which was signed into law under the Clinton administration in May 2000. The scheme provides selected African countries with the most liberal access to American markets available to any country with which the US does not have a Free Trade Agreement. It initially proved to be a useful tool with which to respond to the increasing disenchantment with the Washington Consensus development model. In its early days, the AGOA scheme 
provided some tangible benefits to eligible African countries, especially in the area of textile and garment exports, but also in certain agricultural areas, for example, the exporting of cut flowers. The AGOA was greeted with enthusiasm in Africa, particularly in the way that it represented a shift in the old development thinking away from conditional aid packages to something Africans themselves had been requesting for a long time - a more explicit focus on trade and market access to enhance their growth.

The figures for African exports to the US of both textiles and clothing in the first five years of the AGOA demonstrate how this sector in particular boomed. This situation was enhanced by the fact that the Multi Fibre Agreement (MFA) was still in place. The MFA was enacted in 1974 in order to protect the developed world's textile and garment manufacturers from developing world exports through a system of quotas on what the developing world could export. It was instigated because of concern in the West that the labour intensive nature of this sector would give the developing world a natural advantage due to their low labour costs. The MFA acted as a barrier to Asian textile exports to the developed world, during which time African exporters we able to build up their exporting base, supported by the AGOA. Overall, sub-Saharan Africa's apparel exports grew by 130 per cent between the enacting of the AGOA in 2000 and the expiry of the Multi Fibre Agreement on $1^{\text {st }}$ January 2005. Particular beneficiaries during this period were: Kenya (a 529 per cent increase in textile and clothing exports to the US); Swaziland (a 455 per cent increase); Malawi (276 per cent); and Lesotho (225 per cent). The combination of AGOA's favourable entry rates and the blocking of Asian competition via the MFA combined to provide remarkably favourable conditions for African exports, but the timing of this opportunity was brief. When 
such opportunities do arise, it is crucial that African governments enact policies and streamline bureaucracy in a manner which would support the restructuring of their industries during these boom times in order for them to remain competitive in a more open market. This they failed to do in this instance, but the fault did not lie solely with them.

The benefits of the AGOA to African exporters have been tangible, but there are a number of significant limitations which have stymied any real embedding of these gains. The first of these reflects problems with the structure of the AGOA itself. A vital aspect of this system is the time scale. AGOA waivers are only granted for one year at a time, and the AGOA itself is only guaranteed for three years. It is simply not possible for African industries to make long term investment and planning decisions predicated on market access which could prove only (very) temporary. There is a further structural problem within the AGOA: the Rules of Origin (ROO) component. These ROOs dictate how much value the imported constituents used in the final export can contribute to the overall value of the product. If the rules are too tight, they can negate any potential benefit for African exporters: for example, a Kenyan garment with a Chinese zip attached could be made ineligible for preferential access if ROOs are not sufficiently fine tuned to allow for this. On the other hand, if the ROOs prove too lax, any Chinese product could pass though an African country with a 'made in Namibia' label on it, once again nullifying the intended benefits for the African exporter. ${ }^{8} \quad$ Despite these issues, the AGOA initially proved to be of real assistance in the growth of African textile and garment manufacturing. The whole enterprise, however, has resulted in an empirical example of Collier's warning - the 
fact that this window of opportunity is brief. For certain critics, the culpability for slamming that window shut lies firmly with China.

\section{African trade: the case against China}

Although Beijing has endeavoured to present itself as a 'development partner' to Africa, concern has been growing with regard to the negative impact Chinese exports have had on African trade. When the MFA was dismantled in 2005, the playing field was levelled once more, and the result was a big surge in competition in this export market, with Chinese exports to the United States being a particular problem. This direct competition led to a wave of job losses across southern Africa in the sector that had grown as a direct result of the favourable provisions of the AGOA. In Lesotho 28.9 per cent of the clothing sector workforce lost their jobs, in South Africa the figure stood at 12 per cent of the total employed, and in Swaziland the figure reached a catastrophic 56.2 per cent. In these three countries alone, this translated into 45,000 job losses in the clothing sector. ${ }^{9}$ African trade unions have blamed China for damaging African manufacturing, with Nigerian trade unions blaming Chinese imports for the loss of 350,000 jobs across all sectors in Nigeria alone. ${ }^{10}$ So intense was the criticism from African press and trade unions that the Chinese were prompted to implement a two year self-imposed quota system at the beginning of 2007 to allow the African textile industry time to adjust. This example illustrates both the efficacy of preferential market access in helping African sectors to grow, but also how fragile the benefits of these limited conditions can be.

The growing criticism of China in Africa does not focus solely on the threat posed by competition from Chinese exports. Union movements and commentators alike are 
now also beginning to accuse China of a 'recolonization' of Africa. A number of studies have predicted that China's method of doing business is set to repeat the old trading patterns whereby Africa's primary products and raw commodities will be exchanged for finished manufactured goods from Asia. ${ }^{11}$ Business Day reported the International Textile, Garment and Leather Workers Federation's Africa chapter as stating: 'Increasingly, the trade pattern between the African continent and China is becoming colonial in character, with African countries exporting raw materials to China and importing finished products'. ${ }^{12}$ This accusation is reiterated in the West, where China's intent is often characterized as a malign plan to establish control over Africa's natural resources - to the detriment of the West. The World Bank reports that the majority of projects in sub-Saharan Africa funded by Beijing '....are ultimately aimed at securing a flow of sub-Saharan Africa's natural resources for export to China'. ${ }^{13}$ A report by the European Parliament also asserts that Chinese interest in Africa, and its aid disbursements, are limited to resource-rich countries only, bypassing other African nations. ${ }^{14}$ It is certainly true that China's rapid growth has resulted in a pressing need for increased imports of natural resources, but further analysis undermines the growing belief in a Beijing-orchestrated master plan focused on transferring the natural resources of the African continent back to China. In fact, China does not bypass any African country with which it has good diplomatic relations: 'China gives aid to every single country in sub-Saharan Africa that follows the One China policy'. ${ }^{15}$ In addition to this, it is important to note that China does not only concentrate its investment in raw material extraction. Brautigam argues that, while resources matter, China's approach is about generating business, with the Chinese involved in a whole range of sectors. She quotes a Nigerian diplomat in Beijing who explained: 'The Chinese are trying to get involved in every sector of our 
economy. If you look at the West, it's oil, oil, oil, and nothing else'. With regard to the idea that Beijing is orchestrating this resource exploitation, researchers argue that it is individual Chinese companies, who enjoy considerable freedom of manoeuvre, who are in the vanguard of this activity. In fact, these companies are under no obligation to export their oil back into China, and they can sell it to wherever they can get the highest price. As a Chinese mining supervisor explains: 'China is so far away, expensive to get to. I would rather just deliver the money' ${ }^{16}$

A number of further considerations are making Africans question whether their initial indiscriminate enthusiasm for Chinese involvement was misplaced. The huge influx of Chinese companies means that some of China's own low standards of employment are also being imported along with the Chinese workforce. ${ }^{17}$ It should be noted that many African companies, particularly small to medium-sized operations, also have a well-established record of flouting employment laws, but the sheer scale of Chinese involvement has helped to maintain a downward pressure on both wages and workers' rights. In addition to these factors, Taylor points to the issue of Chinese intellectual theft, whereby Chinese immigrants are copying traditional African designs particularly in the textile market - manufacturing them from cheap materials, and then undercutting the indigenous manufacturers and the traders at the local markets. ${ }^{18}$ It is clear that the rapid nature of China's engagement has brought a number of negative consequences to the African continent. Throughout the continent, however, the impact of Chinese trade on individual African countries and sectors is not uniform.

\section{African trade: the case for China}


It is important to distinguish between both the competitive and complementary impacts of Chinese imports and exports. Some scenarios are synergistic: for countries producing goods that Africa exports and China imports there will be a significant gain. This largely refers to the hard commodity and oil exporters such as Nigeria, Angola, Zambia, Sudan and South Africa. Likewise, for those products that China exports and Africa imports, there is benefit. Many basic consumer goods and some capital goods are now within the reach of many Africans who would have previously not been able to purchase them. However, in sectors where both China and Africa compete to export, Africa will find itself at a significant disadvantage. The negative impact of the fierce competition in clothing and textiles was demonstrated - as we have seen - with the dismantling of the MFA in 2005. The impact on employment has devastated some areas of the community in Lesotho, Kenya, Madagascar, Mauritius, South Africa and Swaziland. A disadvantageous scenario will also arise in sectors where both China and Africa compete to import the same goods. This is especially the case with hard commodities - most particularly oil - and African importers will be certain to suffer from the upward pressure on world prices caused by China's soaring demand. ${ }^{19}$

As these varied impacts show, it is possible to forward a more balanced approach to what the rise of China might mean. Ngaire Woods quotes an OECD study which concludes that there is some evidence that countries with increased trade and aid links with China have higher growth rates, better terms of trade, increased export volumes and higher public revenues. ${ }^{20}$ There also appears to be less of a disconnect between China's aid and trade policies. Alden identifies these factors as reflecting China's 'carefully constructed foreign policy of 'rayonnement', or 'overarching brilliance'. ${ }^{21}$ 
In a short space of time, China has successfully matched the western development actors, and has framed its cooperation in terms of solidarity. In South Africa, for example, a sharp rise in Chinese clothing imports has been blamed for the crisis in that country's clothing industry. The Chinese response has been to fund a US $\$ 2.5$ million training programme in South Africa's garment industry, and to promise preferential loans to assist the modernization of the textile industry. ${ }^{22}$ This aspect of policy in particular has been well received in the recipient countries. It is also possible that China's aid and investment can provide the right conditions for Africa's 'take off':

Chinese factories offer not only jobs - they also use production technologies that African entrepreneurs can easily adopt...African elites keep some 40 per cent of their wealth outside the continent, far more than the Asian average of only 6 per cent. Chinese firms...could offer incentives for some of that wealth to return to a capital-starved region. ${ }^{23}$

Beijing's rejection of the former colonizing powers' patronizing approach to Africa, together with its inclusion of a significant trade and investment programme, demonstrates that it intends China's role as donor to contrast with the donors of the West: a 'silent revolution' in development assistance. ${ }^{24}$

The Washington Consensus was being questioned even before the global economic crisis hit. The system of Anglo Saxon free-market capitalism was being challenged as a reflection of western excesses that was neither sustainable nor possible for recipient governments to follow. This was in contrast to the relatively insulated Chinese economy which appears to offer hope as a model to developing countries today. As China gradually responds to the varied criticisms of its policies, there are times when 
it looks more like a development partner to those recipient African government with which it engages. Its willingness to listen and adapt on areas such as worker rights and safety, its funding of ventures run solely by African entrepreneurs through the use of the China-Africa Development Fund, its tougher stance towards Harare and Khartoum and its increased willingness to cooperate with the United Nations and the WTO all indicate that Chinese foreign policy is about more than creating a league of dictators with the sole aim of securing natural resources at the expense of the West. For as long as a belief in American exceptionalism persists, however, any evidence of the benign nature of certain elements of Chinese engagement will hold little comfort. Improved economic circumstances in Africa are clearly desirable, but not necessarily at the cost of Washington's influence.

\section{Part II}

\section{The US, China and African Governance}

\section{The Chinese threat to good governance}

China's rapid rise as a significant actor in the arena of African development prompted much concern in Washington in particular, with observers damning its interference in the strongest possible terms. China's toxic aid was, it was argued, about to undermine all the years of careful progress that had been nurtured by the Washington model of conditional assistance. Kagan warned that China's policy of non-interference in the domestic affairs of recipient states was amounting to an 'informal league of dictators'. Well-documented dealings with the brutal regime of al-Bashir in the Sudan and China's funding of controversial patrol boats in the delta region of Nigeria have all been reasonable grounds for concern in the West. 
Within Africa too, China has been heavily criticised for its lack of transparency and disregard for human rights which some argue has led directly to maintenance of dictators in power, and the avoidance of true development. ${ }^{25}$ It is not difficult to see why dictators might welcome some of China's actions, even while they are rejected by African civil society. Certainly, China's initial pride in its 'no strings attached' development assistance was most appealing to African leaders, who had become accustomed to sitting through lectures from their western donors. A resurgence of support for the 'prestige projects' beloved by so many African dictators over the years demonstrated that China's contribution could turn back the western good governance agenda in Africa. Washington became increasingly concerned as more African states managed to use Chinese aid in order to sidestep the institutions which are the foundation stones of the Washington Consensus. Negotiators at the IMF watched in frustration as their carefully crafted 2005 loan to Angola, which included conditions on the reform of the government, was abandoned by the Angolan government in favour of a huge package of soft loans from China. There was a similar story in Chad when a World Bank loan, negotiated to include some significant poverty reduction measures, was scrapped in light of alternative assistance from China. The proposed Mpanda Nkuwa dam in Mozambique was greeted with concern by many stakeholders in Mozambique, but the environmental and social concerns could be overlooked by the government when the Chinese agreed to step in and provide funding.

Initially, the Chinese government was perfectly happy to weather the criticism, because they were determined to maintain a policy of non-interference. As Pambazuka reported, Chinese diplomats were proud to announce: 'Non-intervention 
is our brand, like intervention is the Americans' brand'. ${ }^{26}$ Politically illiberal China provides an example of notable economic success, 'which stands in stark contrast to the prescriptions of the Washington Consensus ${ }^{27}$ and could leave Washington with significantly reduced leverage on the African continent. Indeed, a lack of ideological zeal has been one of China's greatest assets in its meteoric rise in development circles. The wisdom of Deng Xiaoping's recommendation that China's foreign policy should include a focus on '...maintaining a low profile, [and] never claim[ing] leadership...' stands in contrast to the often clumsy and sometimes counterproductive attempts of the West, and the US in particular, to champion its own ideological vision through its development assistance. ${ }^{28}$

Advocates of the Washington Consensus model, however, warn that far worse outcomes will result if the western model of development assistance is replaced by a 'Beijing Consensus' holding sway in Africa. ${ }^{29}$ Washington's argument was that the International Financial Institutions (IFIs) had come some way in pursuing their carefully constructed 'good governance' agenda and that the conditionality underpinning many of the development programmes was crucial in strengthening support for this goal. In fact, the Chinese have found it necessary to step back from their trumpeted policy of non-interference, most notably on the Sudan and Zimbabwe. Beijing has grown increasingly sensitive to the criticism levelled at it by the rest of the international community for its dealings with these pariah states, and this has had an effect on the direction of its engagement. Even more to the point, however, was the fact that Beijing soon came to realise that doing business with governments that were suffering from endemic corruption and instability did not make for good investment conditions. The whole development agenda has become more complex 
for Beijing as they come to the realization that a basic level of stability and integrity is desirable among recipient governments.

\section{The Washington Consensus - what is at risk?}

The Washington Consensus places great emphasis on economic and political freedom. The latter, together with an increasing international interest in the notion of human rights, and a reignited belief in American exceptionalism, formed the basis of much of the later conditionality in aid programmes. The evangelical approach of the liberal internationalists overlapped with the beliefs of the neo-conservatives in the area of democracy promotion, if not in the methods to pursue it. The stumbling of the Washington Consensus reflects Vaclav Havel's argument that practitioners in the field of international relations do the greatest harm when they have an unshakable belief that they possess universal solutions to the problems of the world. Many African governments would agree with this criticism, remembering from bitter experience the negative effects that can result from the blind promotion of a 'one-size-fits-all' development model being urged onto disparate societies across the continent by their influential donors and the powerful multilateral donor organisations. Over the last decade, some African leaders have become more confident to speak out against the prevailing development Consensus. Former Mozambican President Joachim Chissano criticised the way in which African concerns on local infrastructure and the need to grow the local private sector had been 'systematically dismissed' by western donors. $^{30}$

A further problem is one that blights every aspect of development policy. This obstacle is represented by the competing agendas within the donor community, and 
the fact that competing perceptions of national interest will result in conflicting priorities in development programmes, many of which have little to do with development. One such example is 'PD20', enacted by the US Congress in 1994 to prohibit the US Agency for International Development (USAID) from providing any funding if it was 'reasonably likely' that the result of the funding would lead to any job losses in the United States. ${ }^{31}$ This immediately precluded assistance in growing local private sectors within recipient economies, which contrasts with China's promise to assist with the modernization of South Africa's textile industry. It has been the experience of these conflicting agendas which has resulted in so much hostility among recipients, made far worse by the fact that such 'assistance' is accompanied by lectures on good governance. China's approach, on the other hand, can be summed up in the pithy conclusion of Jeffrey Sachs, when he stated, 'China has a very pragmatic approach. It gives fewer lectures and more practical help' ${ }^{32}$

The continued commitment to American exceptionalism is illustrated in the Department of Commerce's assessment of the AGOA programme, as contained within its annual US-African Trade Profile. Individual African countries have to qualify to be accepted as beneficiaries of the scheme, and the Act authorizes the President to designate countries as eligible to receive the benefits of AGOA if they are determined to have established, or are making continual progress towards establishing the following: market-based economies; the rule of law and political pluralism; elimination of barriers to U.S. trade and investment; protection of intellectual property; efforts to combat corruption; policies to reduce poverty, increasing availability of health care and educational opportunities; protection of human rights and worker rights; and elimination of certain child labour practices. ${ }^{33}$ These criteria 
demonstrate that Washington is unwilling to jettison its commitment to conditionality in development assistance. At face value, despite the potential challenge to sovereignty posed by such conditionality, it would be hard to argue against the beneficial nature of the reforms upon which Washington is insisting. The pressing need to improve African governance is, unarguably, crucial. It is this belief that has led some commentators to lament the rise of China in the development arena and to argue that China's approach will undermine the improvements in African governance that are contingent upon Washington's conditionality. This presupposes, however, that Washington's conditionality has a proven efficacy in this area.

Much has been made of China's insatiable resource hunger as being the driving force behind its Africa policy. An examination of the way in which the AGOA is being utilized by American importers, however, demonstrates that the roots of this development tool appear little different. Figures for 2008 demonstrate that US imports from Africa under the auspices of the AGOA remained highly concentrated among a small number of countries, namely Nigeria, Angola, South Africa and the Republic of Congo. (Considering that these four countries accounted for 83.7 per cent of US purchases in 2008, this would appear to negate some of the vehement criticism levelled at China in its dealings with Angola. Beijing's soft loan unquestionably aided the Angolan government in sidestepping the conditionalities required of a major IMF loan, but US imports of Angolan oil also contribute hugely to that government's coffers.) Resource acquisition is just as significant in US imports from Africa as it is to the Chinese, with oil imports accounting for 82.8 per cent of all US purchases in 2008. The second highest US import from the continent was platinum, accounting for a further 3.5 per cent. US investment, too, is heavily 
concentrated in the extraction of natural resources, with all the implicit problems this type of investment brings, often including a skewed economy suffering from Dutch disease. While Washington might lament China's indiscriminate investment and boasts of non-interference, judging by the oil-exporting primary beneficiaries of the AGOA, it seems that the boost to good governance provided by the conditionality of the AGOA is not particularly beneficial either.

No foreign policy can emerge unscathed from the implementation process. High hopes and laudable donor aspirations of encouraging and cajoling African governments away from corruption and mismanagement and towards a transparent and efficient state apparatus are always hijacked by myriad national interest considerations. These may be resource-based, economic, political or cloaked in terms of national security, but they must always be taken into account when assessing the likely impact of any policy. The AGOA, for example, looks like a useful and (the crucial point) mutually beneficial instrument for growth. It addresses some of the issues that the African governments have been calling for for decades, for example, the re-prioritizing of trade and investment over Washington-centric conditional aid handouts. By the time the development benefits have been watered down by the economic considerations of the Department of Commerce, then the challenges in Congress, followed by a filtering through the often corrupt structures of the recipient government (and sometimes the corrupt structures of the western businesses involved), the result is what we see today: a system funded by the American taxpayer which mainly facilitates the smooth running of the same exploitative colonial relationships of trade - the export of oil, minerals and, particularly after the demise of the MFA, unprocessed, non-value added materials. 
In addition to these factors, the appeal of the West has been further diminished by the economic crash, which has called into question the very nature of the model the West has been trying to sell. A good deal of America's influence has been derived from the 'soft power' of the strength of the brand of market-based capitalism. ${ }^{34}$ The way in which the power of this brand has been undermined by the crash has led to a further undermining of US influence. This has exacerbated trends showing that it is not just the American economic model which has suffered damage. In a wide ranging poll conducted by the Pew Research Center in 2007, the approval ratings on 'American Ideas about Democracy' had fallen almost unanimously across the board since 2002. ${ }^{35}$ It has been in this context - the decline of American popularity, the economic crash and especially the rise of an alternative donor approach as represented by China - that the Washington Consensus has been so badly damaged.

The arguments for supporting the West's good governance agenda become weaker the more scrutiny they undergo. It would be impossible to argue against the need for improvements in African governance, but the programmes put in place to improve governance have, all too often, been weak, ineffectual, and undermined by conflicting vested interests from donors and recipients alike. As Brautigam explains, 'Critics described the process as an elaborate charade: aid recipients pretending to reform, and donors pretending to believe them'. ${ }^{36}$

\section{Will African governments squander their chance?}

Criticism of the scale of Chinese growth and investment and its impact on African manufacturing and growth has an element of scapegoating to it. African governments 
were aware that the provisions of the MFA and the protection it afforded were only temporary, yet there is little evidence that they took steps to avoid the inevitable ramifications of the post-MFA increase in competition. China was able to benefit hugely from the lifting of these trade restrictions, although some aspects of their success are indeed more controversial. (The fact that the Yuan has long been undervalued by up to 40 per cent has been a source of international contention.) However, Beijing also utilized more positive measures to ensure that Chinese manufacturing would thrive in the open markets. The Chinese government provided its textile industry with billions of dollars worth of "free capital, direct and indirect subsidies, and a host of other "incentives" to drive competitors out of the markets'. ${ }^{37}$ It would be unrealistic to suggest that African governments were in a position to offer a similar level of support to their domestic enterprises. What can be argued, however, is that many of the governments of individual African states allowed corruption and mismanagement to squander what potential benefits could have been achieved before the MFA was dismantled. For example, when the South African government took the step of imposing its own quotas on Chinese textile imports, these imports duly dropped by around 35 per cent, but aggregate imports in these areas only marginally decreased. Imposing the quotas without simultaneously establishing either direct support of local enterprise or a more efficient and transparent business environment has meant that countries such as Pakistan and Vietnam, rather than local manufacturers, have instead filled the gap in the market created by the quotas imposed against China. $^{38}$

For decades, African governments have been calling for a focus on trade and investment, rather than a reliance on a flawed aid system. But, fifty years after 
decolonization, insidious corruption and bad governance within African states are undermining development, just as much as the unfair terms of trade imposed on them by the more powerful actors of the West. Some of the policies that have been enacted appear to provide little benefit to ordinary African citizens. With their tiny domestic markets, it is easy to question what many African governments hope to gain by adopting high trade barriers. Collier gives one reason - because they are key sources of corruption. On the grand scale, governments can bestow protection on companies that have either given bribes for the privilege, or are owned by those who happen to be related to the key members of the governing party. On the level of petty corruption, becoming a customs officer provides daily opportunities to engage in bribe-taking, and can prove extremely lucrative. ${ }^{39}$

Members of Mozambican Civil Society Organisations have criticized China for its weak environmental and social requirements, its lack of human rights protections and its policy of non-interference. They conclude: 'The result has been dictators maintaining power, centralising wealth, and avoiding true development. ${ }^{40}$ Yet these conclusions beg the question - where does the culpability ultimately lie? When necessary, China and its state-backed MNCs are perfectly capable of working within the rule of law, at least to the (occasionally dubious) standards of the average western company. In the example of the better-regulated and better-governed South Africa, Chinese MNCs have had little difficulty abiding by the rules and working within the law. When Ellen Johnson-Sirleaf was elected president in Liberia, she threw out the unfavourable terms of an iron ore deal with the Indian conglomerate, Mittal, and renegotiated a better one. She also began a review of the terms granted to Chinese investors. $^{41}$ The MPLA government in Angola surprised its Chinese partners in 
March 2007 when it reversed the decision to award Sinopec the right to construct the oil refinery in Lobito. Angolan officials complained that the facility was only aimed at supplying the Chinese market and stated that they were unwilling to be locked into long term supply contracts. ${ }^{42}$ This demonstrates that African politicians are not without influence over the actions of these great or rising powers when operating within their own borders. Indeed, the longer-term possibility of a shift to a multipolar world could give rise to an element of competition from which African governments could benefit. When the Chinese expressed an interest in establishing an economic zone in Mauritius, it was initially designed to fulfil some of China's 'restructuring' aims - moving some polluting sunset industries across to a new industrial hub in Mauritius. After negotiations with the Mauritian government, however, the design was changed to a far more service- and technology-based city, with the light industry aspect outweighed by an emphasis on higher value-added investors. $^{43}$ The government had not lost sight of the overall impact of the development for the whole country, with much of it being dependent on tourism. By focusing on the overall interests of the population, the Mauritian government had succeeded in achieving a development of potentially substantial benefit for the citizens of that country. This can be compared with the example of the establishment of an export-processing zone in Madagascar in the late 1990s. Good economic policies enabled firms to become cost-competitive, and the provisions of the AGOA, enacted in 2000, came at just the right time for these Madagascan firms to take advantage of its provisions. From an almost standing start, there was a rapid and huge growth in employment, with 300,000 jobs being created in the zone 'almost overnight'. ${ }^{44}$ Unfortunately, the Madagascan people soon became victims of an alltoo-common example of appalling African governance. When President Ratsiraka 
lost the election in December 2001, he refused to step down, and blockaded the Madagascan port of Toamasina in order to unseat his rival, Marc Ravalomanana. This economic strangulation continued for eight months, during which time the export processing zone suffered serious damage. Collier recalls the manager of an American garments firm witnessing the former president's attempt to destroy the economy of his own country with disbelief, saying, 'If it's like that, then count us out. We'll stick to Asia' ${ }^{45}$

Again, China comes in for criticism from African commentators for their involvement in illegal logging in Zambezia province, Mozambique. Further investigation, however, demonstrates the way that this involvement is only made possible through the collusion of the Mozambican government. Justica Ambiental (Friends of the Earth Mozambique) explains that a checkpoint to monitor logging in the province concentrates on villagers with small amounts of timber, while those operators with links to politicians are not detained or checked. Legislation stipulated that the main commercial species of logs had to be processed before export - most of which were being exported to China. In complicity with the logging industry, the government has now added a special regulation which reclassifies the timber and allows their export as logs. This in turn undermines local industry and transfers the possible value-added benefits to China. The conclusion of Justica Ambiental is that China is facilitating illegal logging and obstructing sustainable development in the area, but the fact remains that if the government did not pursue corrupt relations with the logging industry, and passed legislation with the benefit of all Mozambicans in mind, China would have far fewer opportunities to exploit. 
Corruption also plays a crucial role in the problem of Chinese counterfeiting in African markets. Not only are laws to prohibit this practice ineffectually policed, there is also evidence to show that some corrupt politicians have a vested interest in maintaining the situation. ${ }^{46}$ In addition to this, the infrastructure - both physical and bureaucratic - necessary to facilitate business activities is severely compromised through inept or corrupt governance. Despite huge gas and coal reserves, Nigeria can only manage to generate around half of the power needed to meet domestic demand. In February 2007, Nigeria announced that its power generation had dropped by almost 60 per cent, despite the government's claim to have invested over US\$2 billion in the sector in the previous six years. ${ }^{47}$

\section{Conclusions}

In a distorted reflection of the Cold War, Africa once again runs the risk of being caught in the crossfire of the competing agendas of East and West. This time the terms of the debate are centred on economic national interest and, crucially, one of the parties is not driven by the need for ideological evangelizing. The rise of China has presented both obstacles and opportunities in Africa's quest for growth. It is impossible to assess the impact of China's growth in Africa in any uniform way, largely due to the fact that diverse countries, and diverse sectors within countries, have experienced very different challenges in relation to China's direct and indirect pressures. The push for influence from both the Washington Consensus and the Beijing Consensus has given African statesmen and women a measure of influence over their own destinies. Concern over these competing influences has, however, cast a spotlight on the fact that neither agenda will provide Africa with a definitive path to development. Any benefit offered by China's increased involvement on the continent 
is contingent upon there being a sufficiently transparent and efficient government and bureaucracy in place to oversee it. Although it is argued that it is this very system that the influence of Beijing would threaten, the competing agendas of Washington policy makers have also failed to secure it. China's role as development partner is likely to follow the pattern set by Washington. Trade preferences and aid programmes will only be furthered in as far as they meet a donor's interests - and no significant assistance will be offered by either power in sectors of the economy which may compromise donor interests.

The renewed element of competition which has been introduced onto the development agenda ought to provide African governments with some degree of autonomy in the international sphere, but it also increases their responsibility. If Africa is to capitalize on this limited window of opportunity, it needs a generation of leaders and parliamentarians who are prepared to build an environment conducive to investment and to the support of local industry. If countries across the continent continue to be blighted by the scourge of corruption, infrastructure will be undermined as funds are channelled away from its improvement. Bureaucracy will continue to act as a brake, rather than a facilitator for growth, and the competing influence of the US and China on the continent will remain academic for Africa's people while governments provide an environment which allows either country to harvest what it can from Africa with little regard to the citizens of the continent.

The small chance offered by the newly introduced element of competition between America's and China's development agendas means that, despite their ultimate focus on their own national interest, these powerful donor states might be more inclined to 
offer some compromises to recipient governments in order to secure these same national interests. This unique opportunity means that there are more chances to bargain and potentially more gains to be had from the development paths offered by either power. And yet, regardless of this, some African governments might choose to ensure that their citizens continue to benefit from neither. ${ }^{48}$

\footnotetext{
${ }^{1}$ See D. Brautigam, The Dragon's Gift The real story of China in Africa, Oxford and New York: Oxford University Press, 2009, p.11.

${ }^{2} \mathrm{~S}$. Halper, The Beijing Consensus How China's authoritarian model will dominate the twenty-first century, New York: Basic Books, 2010, p.252.

${ }^{3}$ E.B. Kapstein, 'Africa's Capitalist Revolution: Preserving Growth in a Time of Crisis', Foreign Affairs, 88 (4) July/August 2009, p.119.

${ }^{4}$ A. Mattoo, and A. Subramanian, 'From Doha to the next Bretton Woods: a New Multilateral Trade
} Agenda', Foreign Affairs 88 (1) Jan/Feb 2009.

5 B. Klein, and K. Cukier, 'Tamed Tigers, Distressed Dragon: How Export-Led Growth Derailed Asia’s Economies', Foreign Affairs 88 (4) July/August 2009, p.15-6

${ }^{6}$ Kapstein, 'Africa's Capitalist Revolution', 2009, p.128

${ }^{7}$ P. Collier, The Bottom Billion, Oxford and New York: Oxford University Press, 2007, p.166

${ }^{8}$ Collier, The Bottom Billion, 2007, p.169

${ }^{9}$ C. Alden, China in Africa, London and New York: Zed Books, Cape Town: David Philip, 2007, p.80

${ }^{10}$ R. Kaplinsky, 'Winners and Losers: China's Trade Threats and Opportunities for Africa' in L. Wild and D. Mepham eds. The New Sinosphere: China in Africa, London: Institute for Public Policy Research, 2006, p.15

${ }^{11}$ Alden, China in Africa, 2007, p.112

${ }^{12}$ Business Day, $27^{\text {th }}$ September 2005

${ }^{13}$ V. Foster and W. Butterfield, Building Bridges: China's Growing Role as Infrastructure Financier for Sub-Saharan Africa, Washington D.C.: The World Bank, July 2008, p.64.

${ }^{14}$ A. Gomes, Report on China's Policy and its Effects on Africa, Brussels: Report of the European Parliament, A6-0080/2008, April 2008.

${ }^{15}$ Brautigam, The Dragon's Gift, 2009 p.278.

${ }^{16}$ As quoted in Brautigam, The Dragon's Gift, 2009 p.281.

${ }^{17}$ M. Chidaushe, 'China's Grand Re-Entrance into Africa - Mirage or Oasis?' in F. Manji and S. Marks eds. African Perspectives on China in Africa Cape Town Nairobi and Oxford: Fahamu, 2007, p.114

${ }^{18}$ A detailed account of this practice can be found in: I. Taylor, China's New Role in Africa Boulder and London: Lynne Rienner Publishers, 2009, pp.77-80.

${ }^{19}$ Kaplinsky, 'Winners and Losers', 2009 p.19

${ }^{20}$ N. Woods, 'Whose Aid? Whose Influence? China, Emerging Donors and the Silent Revolution in Development Assistance' in International Affairs, 84(6), 2008, p.1208

${ }^{21}$ Alden, China in Africa, 2007 p.35

${ }^{22}$ Taylor, China's New Role in Africa, 2009 p.77

${ }^{23}$ D. Brautigam, Online Debate Council on Foreign Relations 13/2/07 as quoted in Alden, China in Africa, 2007, p.129.

${ }^{24}$ Woods 'Whose Aid? Whose Influence?', 2008, p.1221

${ }^{25}$ A. Lemos and D. Ribeiro 'Taking Ownership or Just Changing Owners?', in Manji and Marks eds. African Perspectives on China in Africa, 2007, p.64

${ }^{26}$ D. Large, 'As the Beginning Ends: China's Return to Africa', Pambazuka News, $14^{\text {th }}$ December 2006, www.pambazuka.org

${ }^{27}$ Kaplinsky, 'Winners and Losers', 2009 p.13 


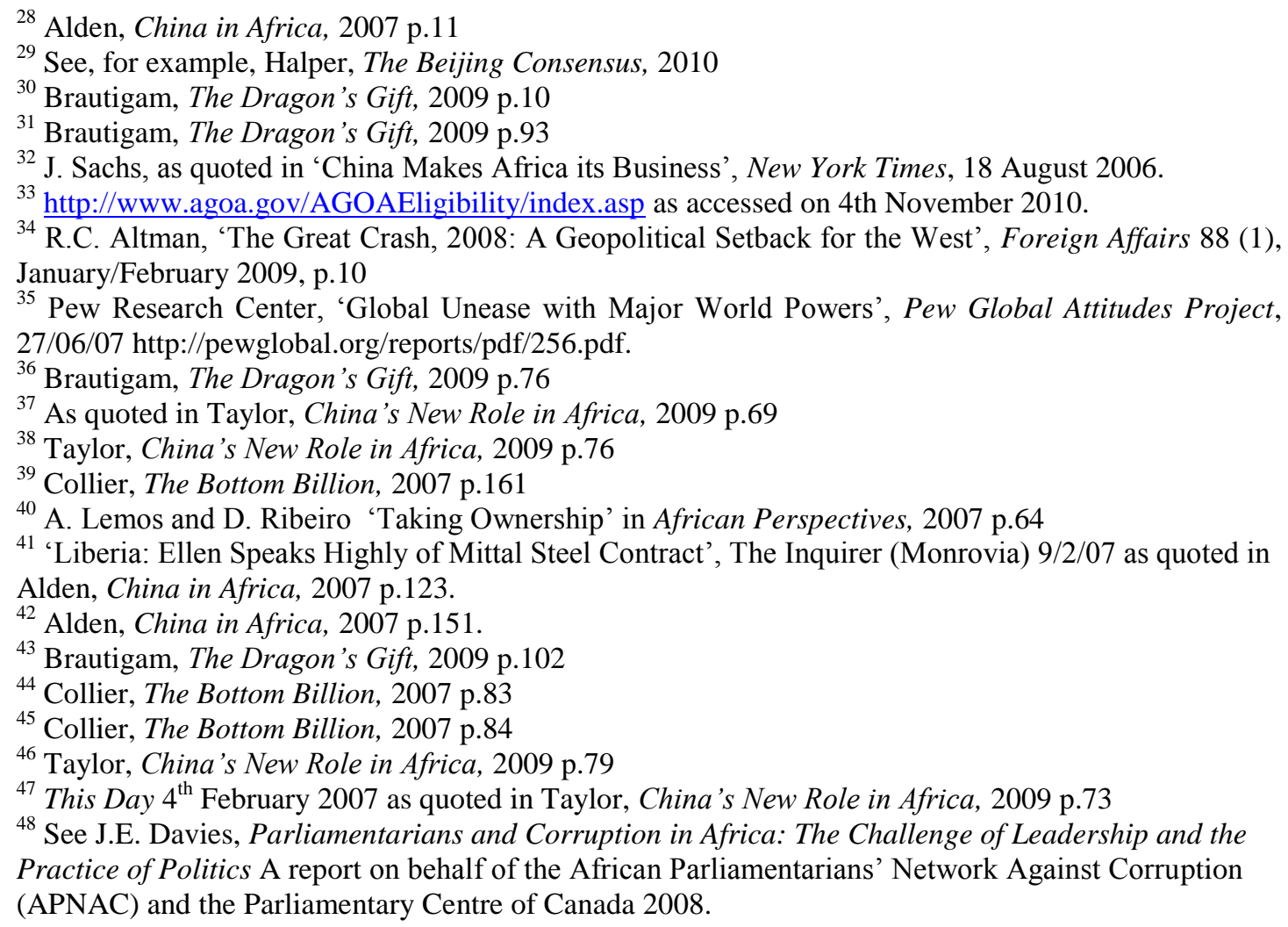

